\title{
Proposal of Purpurea gen. nov. (Nostocales, Cyanobacteria), a novel cyanobacterial genus from wet soil samples in Tibet, China
}

\author{
Fangfang $\mathrm{CAI}^{1,3}$, Yilang WANG ${ }^{1,4}$, Gongliang $\mathrm{YU}^{1}$, Jie $\mathrm{WANG}^{2}$, Xin PeNG ${ }^{1}$, Renhui $\mathrm{LI}^{1 *}$ \\ ${ }^{1}$ Key Laboratory of Algal Biology, State Key Laboratory of Freshwater Ecology and Biotechnology of China, \\ Institute of Hydrobiology, Chinese Academy of Sciences, Wuhan 430072, People's Republic of China; \\ *Correspondence author e-mail: reli@ihb.ac.cn, tel. (+86) 27 68780067,fax (+86) 2768780123 \\ 2 Department of Biology, Taiyuan Normal University, Jinzhong 030619, China \\ ${ }^{3}$ Key Laboratory for Animal Nutrition and Feed Science of Hubei province, Wuhan Polytechnic University, \\ Wuhan 430023, China \\ ${ }^{4}$ University of Chinese Academy of Sciences, Beijing 100049, People's Republic of China
}

\begin{abstract}
A new cyanobacterial strain CHAB5880 morphologically identified to the Nostoc-like genus was isolated from wet soil samples in Tibet of China, and it was taxonomically and phylogenetically characterized based on the polyphasic approach combining morphological, genetic and ecological characteristics. Colonies of this strain were usually purple to black, irregularly clustering, forming diffluent mucilage. The phylogenetic tree based on 16S rRNA gene indicated that the novel strain formed a unique cluster, and separated from the 'Nostoc sensu stricto' clade and from the clades of the morphologically similar genera Aliinostoc, Desmonostoc and Holatia. The secondary structure of ITS between 16S-23S rRNA gene in the strain CHAB5880 showed unique patterns of D1-D1', Box-B and V3 helix, which distinguished it from other heterocytous genera. Purpurea tibecum sp. nov. was designated as the type species of the genus.
\end{abstract}

Key words: cyanobacteria, Purpurea, new genus, polyphasic methods, 16S rRNA phylogeny, secondary structure of ITS, taxonomy

\section{INTRODUCTION}

The taxonomic system of cyanobacteria has undergone several radical and significant revisions (RIPPKA et al. 1979; AnAgnostidis \& KomáreK 1985; HofFMANn et al. 2005a, 2005b). The polyphasic approach combining morphological, ecophysiological, biochemical and molecular characters have been proposed to classify cyanobacterial diversity since it is likely to select some satisfactory common criteria for the characterization of basic cyanobacterial taxonomic units. In 2014, an important update on the taxonomic system of cyanobacteria was proposed to better reflect the combination of phylogeny and morphology, and to effectively describe the cyanobacterial genus (KOMÁREK et al. 2014). Through much efforts on the application of polyphasic approach for cyanobacteria classification during the past decades, considerable progress has been made in systematics and taxonomy of cyanobacteria, resulting in descriptions of a large amount of novel cyanobacteria genera and species (FiOre et al. 2007; BoHUNiCKÁ et al. 2015; GENUÁRIO et al. 2015; Sciuto \& Moro 2016).

The heterocytous taxa have been proven difficult to characterize, and many morphologically well-defined genera are indeed polyphyletic based on molecular phylogenetic analyses. The taxonomy of these heterocytous taxa characterized by filaments with differentiated heterocytes and akinetes, has undergone considerable revision, even establishing new groups at higher level categories, such as new families including Tolypothrichaceae, Godleyaceae (HAUER et al. 2014), Aphanizomenonaceae (KOMÁREK et al. 2014) and Dapisostemonaceae (HentschKe et al. 2016). At genus level, a variety of novel heterocytous cyanobacterial genera were proposed, such as the Dolichospermum (WACKLIN et al. 2009), Sphaerospermopsis (ZAPOMĚLOví et al. 2009), Chrysosporum (ZAPOMĚLoví et al. 2012), Cyanocohniella (KAŠTOvskÝ et al. 2014), Dactylothamnos (FIORE et al. 2013), Roholtiella (BoHUnICKÁ et al. 2015), Macrochaete (BERRENDERO et al. 2016) and Cyanomargarita (SHALYGIN et al. 2017), etc.

Nostocaceae, the largest family in the Nostocales, has received significantly more studies in recent years. Nostoc, the type genus of this family, is a widespread, complicated and commonly encountered group of cyanobacteria, with 104 accepted species based on the updated 
AlgaeBase (GuIRY \& GuIRY 2019). Phylogenetic studies based on 16S rRNA gene sequence have shown that most strains identified as Nostoc do not form a monophyletic cluster (HrouzeK et al. 2005; ŘEHÁKoví et al. 2007; KAŠTOVSKÝ \& JOHANSEN 2008; LUKEŠOvÁ et al. 2009; JOHANSEN et al. 2014; CAI et al. 2019a, 2019b). In order to solve the polyphyletic problem of Nostoc, ŘEHÁKOvá et al. (2007) first described a new genus, Mojavia, which is morphologically similar to Nostoc, but phylogenetically separated from the 'Nostoc sensu stricto' clade. Following this kind of revision, several novel genera including Desmonostoc (HrouzeK et al. 2013), Halotia (GENUÁRIO et al. 2015), Komarekiella (HENTSCHKE et al. 2017), Aliinostoc (BAGCHI et al. 2017), Compactonostoc (CAI et al. 2019a) and Minunostoc (CAI et al. 2019b), which morphologically appear to be Nostoc-like, have been proposed and separated from the 'Nostoc sensu stricto' clade based on the phylogenetic analysis of the 16S rRNA gene. Despite these advances, further revisionary work of Nostocaceae is expected along more new strains isolated and characterized by using both molecular and morphological features.

In this study, a filamentous heterocytous cyanobacterial strain isolated from wet soils in Tibet, China, was characterized applying a polyphasic approach, by using morphological characters, phylogeny of 16S rRNA gene, 16S-23S internal transcribed spacer (ITS) secondary structure, and ecological data. The results allowed us to describe a novel genus Purpurea with the proposal of the type species as Purpurea tibecum sp. nov.

\section{Materials And Methods}

Isolation and cultivation. Samples used in this study were isolated from the wet soil samples in Tibet, China. Strains were smashed into small pieces and fully infiltrated with sterile water before isolation. Unialgal filaments from the visible growths of cyanobacterial thallus samples were isolated by lab-made pasteur pipette under a 100 times magnification microscope (Olympus C31, Japan) and then cultured in screw-capped tubes containing $5 \mathrm{ml}$ of BG11 medium. Isolated strains were subsequently cultivated at $25^{\circ} \mathrm{C}$ under a $12: 12 \mathrm{~h}$ (light: dark) cycle with a photon flux density of $40 \mu \mathrm{mol} . \mathrm{m}^{-2} \cdot \mathrm{s}^{-1}$ from white fluorescent lamps.

Morphological characterization. Fresh cultures of the studied strains were examined with a Nikon eclipse 80i microscope (Nikon, Tokyo, Japan). Trichome size was measured from $\geq 50$ individuals using a Nikon eclipse $80 \mathrm{i}$ light microscope with DS-Ri1 digital camera (Nikon, Japan). The image was analyzed using the NIS-Elements D 3.2.

DNA extraction and PCR amplification. Total genomic DNA was extracted using the modified cetyltrimethylammonium bromide (CTAB) method adopted by NeILAN et al. (1995). Primers pA (EDWARDs et al. 1989) and B23S (GKelis et al. 2005) were chosen for obtaining segment containing $16 \mathrm{~S}$ ribosomal RNA gene and the associated 16S-23S internal transcribed spacer (ITS) region. The PCR reaction had a final volume of $20 \mu \mathrm{l}$ with $1 \mu \mathrm{l}$ of template DNA $\left(100 \mathrm{ng} \cdot \mu \mathrm{l}^{-1}\right), 0.5$ $\mu \mathrm{l}$ of each primer $\left(10 \mu \mathrm{mol} .1^{-1}\right), 8 \mu \mathrm{l}$ of sterile water and $10 \mu \mathrm{l}$ of $2 \times$ PCR mix with Taq polymerase (Cat TSE001; Beijing Tsingke Biotech Co., Ltd., Beijing, China). The amplification was performed using a BIO-RAD T100 ${ }^{\mathrm{TM}}$ Thermal Cycler (Cat 186-1096; Bio-Rad Laboratories, Inc. California, USA) with a PCR profile of an initial denaturation at $95^{\circ} \mathrm{C}$ for $3 \mathrm{~min}$ at beginning, then a total 35 -cycle melting at $95^{\circ} \mathrm{C}$ for $30 \mathrm{~s}$, annealing at $58^{\circ} \mathrm{C}$ for $30 \mathrm{~s}$ and extension at $72{ }^{\circ} \mathrm{C}$ for $60 \mathrm{~s}$ in the middle and final elongation at $72{ }^{\circ} \mathrm{C}$ for $5 \mathrm{~min}$. The PCR products were analyzed on $1 \%$ agarose gels and DNA strips sized approximate $2200 \mathrm{bp}$ were then purified using TSINGKE DNA Gel Extraction Kit (Cat GE0101-200; Beijing Tsingke Biotech Co., Ltd., Beijing, China) before cloning to vector pMD18-t (Cat D101A; TaKaRa Biotechnology (Dalian) Co., Ltd., Dalian, China). The cloning procedure employed by SAMBROOK \& RUSSELL (2001) was performed. Sequencing was carried out using an ABI 3730 Automated Sequencer (PerkinElmer, Waltham, Massachusetts USA).

Phylogenetic analysis. In this study, the obtained 16S rRNA gene sequences, together with similar reference sequences from the GenBank database, were aligned using MAFFT v7.312 (КATOH \& STANDLEY 2013). Alignments finally formed a matrix of 123 sequences with 1128 nucleotide sites. The most appropriate models of DNA sequence evolution were selected for this dataset by a hierarchical likelihood ratio test using MrModel Test version 3.7 (Posada \& Crandall 1998). The final phylogenetic trees were constructed using maximumparismony (MP), maximum likelihood (ML), and Bayesian inference (BI). The MP analysis using a heuristic search with 1000 replicates was run via MEGA version 7.0.26 (KUMAR et al. 2016), the ML algorithms were performed using PhyML 3.0 (GUINDON et al. 2010) and Bayesian inference were analyzed with MrBayes 3.2.6 (RonQuist et al. 2012). The phylogenetic trees were viewed in FigTree v1.4.3 (http://tree.bio.ed.ac.uk/ software/figtree/). Chroococcidiopsis thermalis PCC7203 was chosen as the outgroup taxon for 16S rRNA phylogeny. Accession numbers for GenBank sequences that were used for phylogenetic analyses were listed as a supplementary file. GenBank accession numbers for our sequences are MN381942, MN381943, MN381944 and MN381945.

Analyses of 16S-23S Internal Transcribed Spacer (ITS). 16S-23S rRNA ITS secondary structures of D1-D1', Box-B and $\mathrm{V} 3$ helices were determined using RNA structure, version 5.6 (Mathews Lab 2013).

\section{RESULTS}

\section{Purpurea F. Cai et R. Li gen. nov.}

Description: In nature, growing on the wet soil. Colonies usually purple to black, irregularly clustering, forming diffluent mucilage. In liquid media culture growing attached to the glass walls of the test tubes, filaments aggregated into macrocolonies (up to $1 \mathrm{~mm}$ in diameters). Filaments flexuous, freely entangled, sheath present or not, colorless. Vegetative cells purple, barrel-shaped to cylindrical. Heterocytes spherical or cylindrical, usually develop in intercalary position, 1 to 3 , trichomes divided in the position of heterocyte, leading to 1-3 
heterocytes in terminal. Akinetes oval, varying in color from brown, green to purple,_easily distinguished from vegetative cells, up to $10 \mu \mathrm{m}$ long, up to $7 \mu \mathrm{m}$ wide (average size $7.95 \mu \mathrm{m}$ long and $6.12 \mu \mathrm{m}$ wide), usually in short chains (1 to 8). Akinetes develop intercalarly, usually distant from heterocytes, occasionally appear between two heterocytes.

Type species: Purpurea tibecum F. Cai et R. Li Etymology: The name of genus 'Purpurea' was chosen due to the purple black vegetative cells.

\section{Purpurea tibecum F. Cai et R. Li sp. nov. (Fig. 1)}

Description: Colonies purple to black, forming diffluent mucilage. Filaments flexuous, freely entangled, sheath present or not, colorless. Vegetative cells barrel-shaped to cylindrical, 2.28-3.78-5.34 $\mu \mathrm{m}$ long, 2.66-3.36-4.2 $\mu \mathrm{m}$ wide. Heterocytes spherical or cylindrical, 2.79-3.71-4.92 $\mu \mathrm{m}$ long, 2.66-3.46-4.45 $\mu \mathrm{m}$ wide. Akinetes oval, brown, green to purple, $7.95 \mu \mathrm{m}$ long and $6.12 \mu \mathrm{m}$ wide.

Reference strains: CHAB 5880.

Type locality: Isolated from the wet soil samples in Tibet, China (3046'32.90"N, 9052'14.78"E).

Holotype here designated: Dry material was stored at the Freshwater Algal Herbarium (HBI), Institute of Hydrobiology, Chinese Academy of Science, Wuhan, China, as specimen No. TBCN201701.

Etymology: "tibecum" refers to the place Tibet where this species was located.

Habitat: Free-living on wet soil.

\section{Molecular and phylogenetic analysis}

The evolutionary distance based on the 16S rRNA gene showed that the Purpurea strain containing two clones shared $100 \%$ similarity with each other (Table 1), and similarities to Aliinostoc, Trichormus, Desmonostoc, Halotia and Nostoc were 94.4\%-95.2\%, 95.1\%-95.2\%,
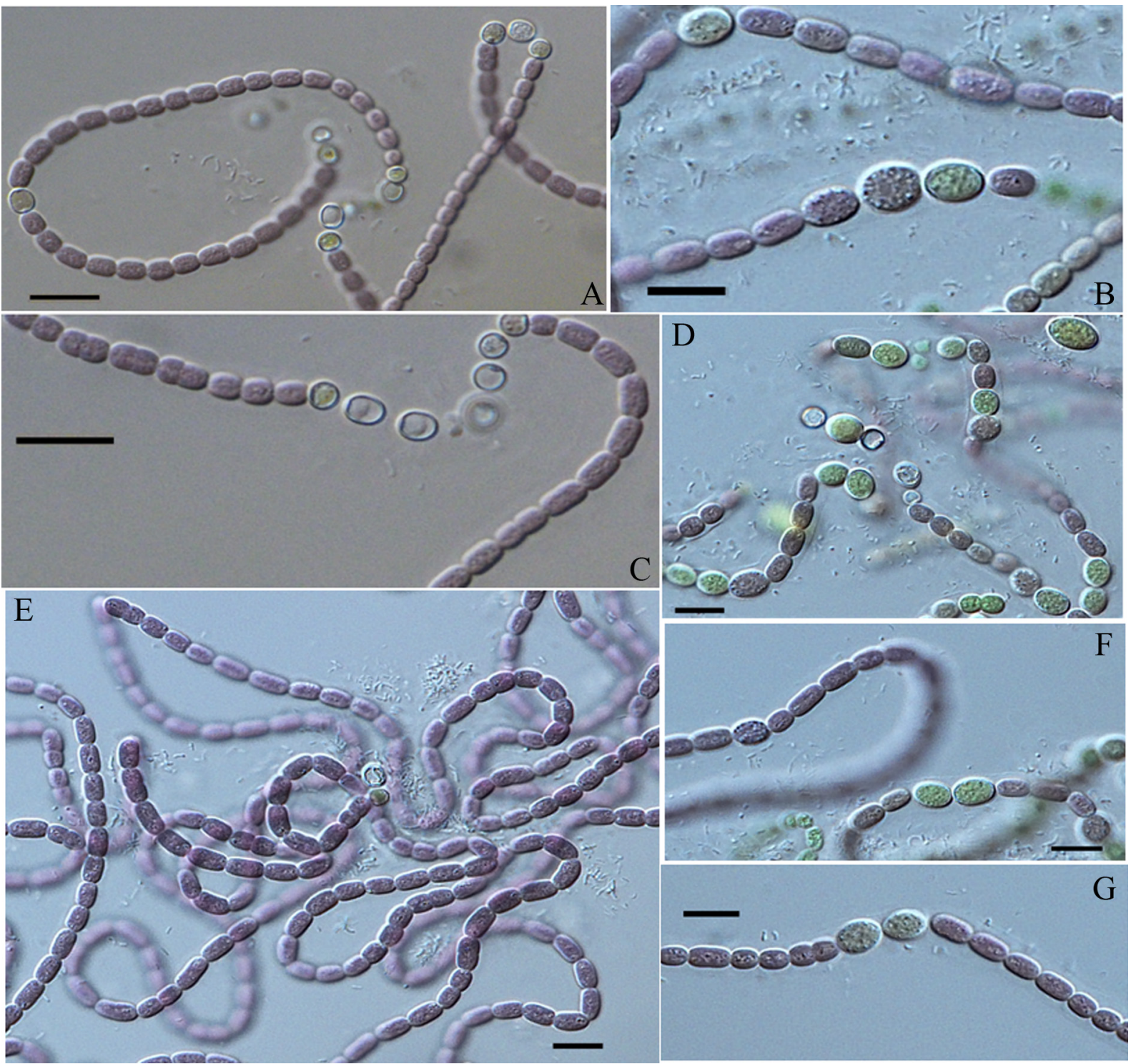

Fig. 1. Micrographs of Purpurea tibecum under the light microscopy (LM): (A) Filaments with internal and terminal heterocytes; (B) Akinetes with different color; (C) Filaments with terminal heterocytes; (B, D, E, F, G) Trichomes wrapped by thin sheath. Scale bars $10 \mu \mathrm{m}$. 


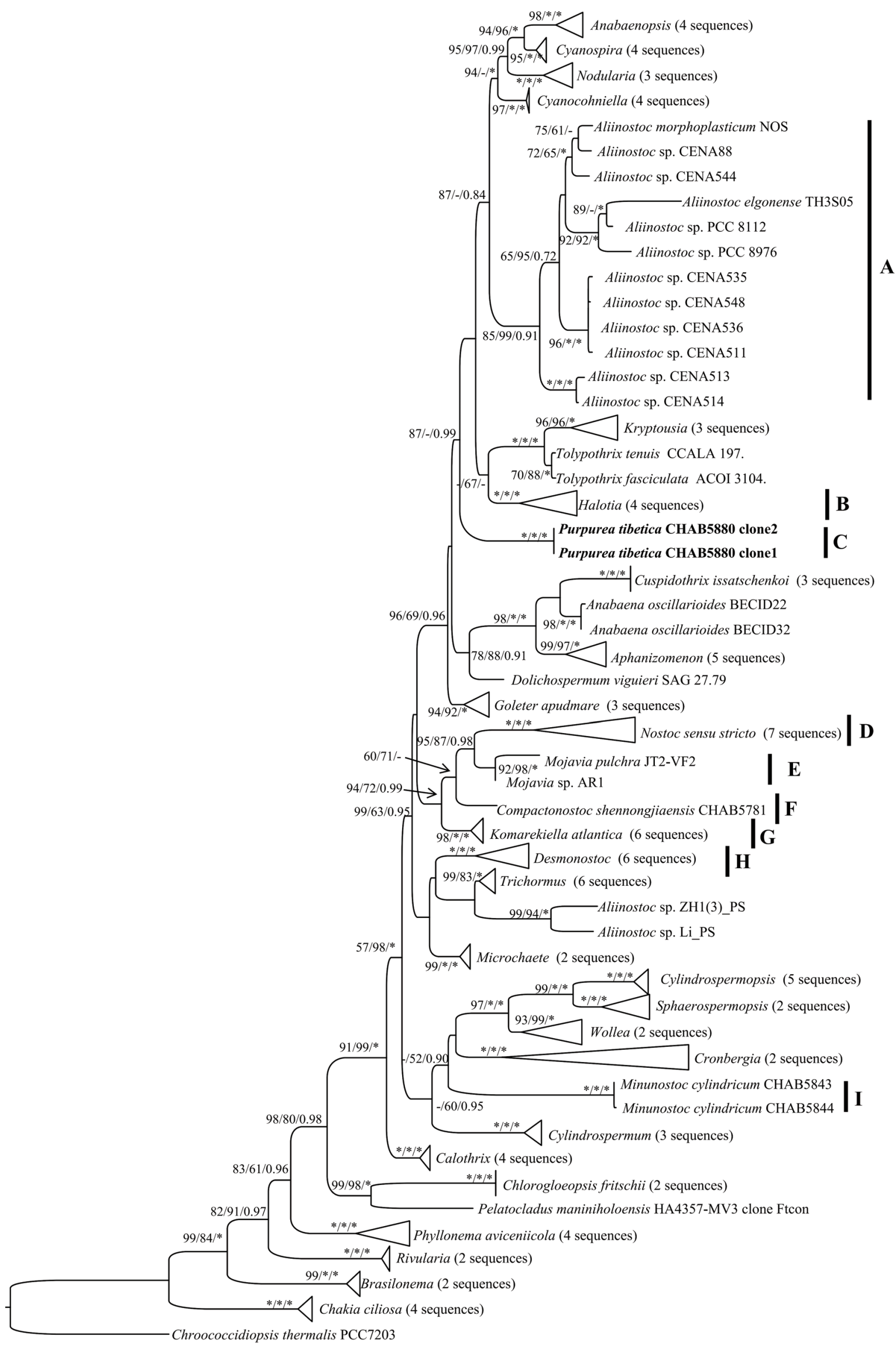

A 


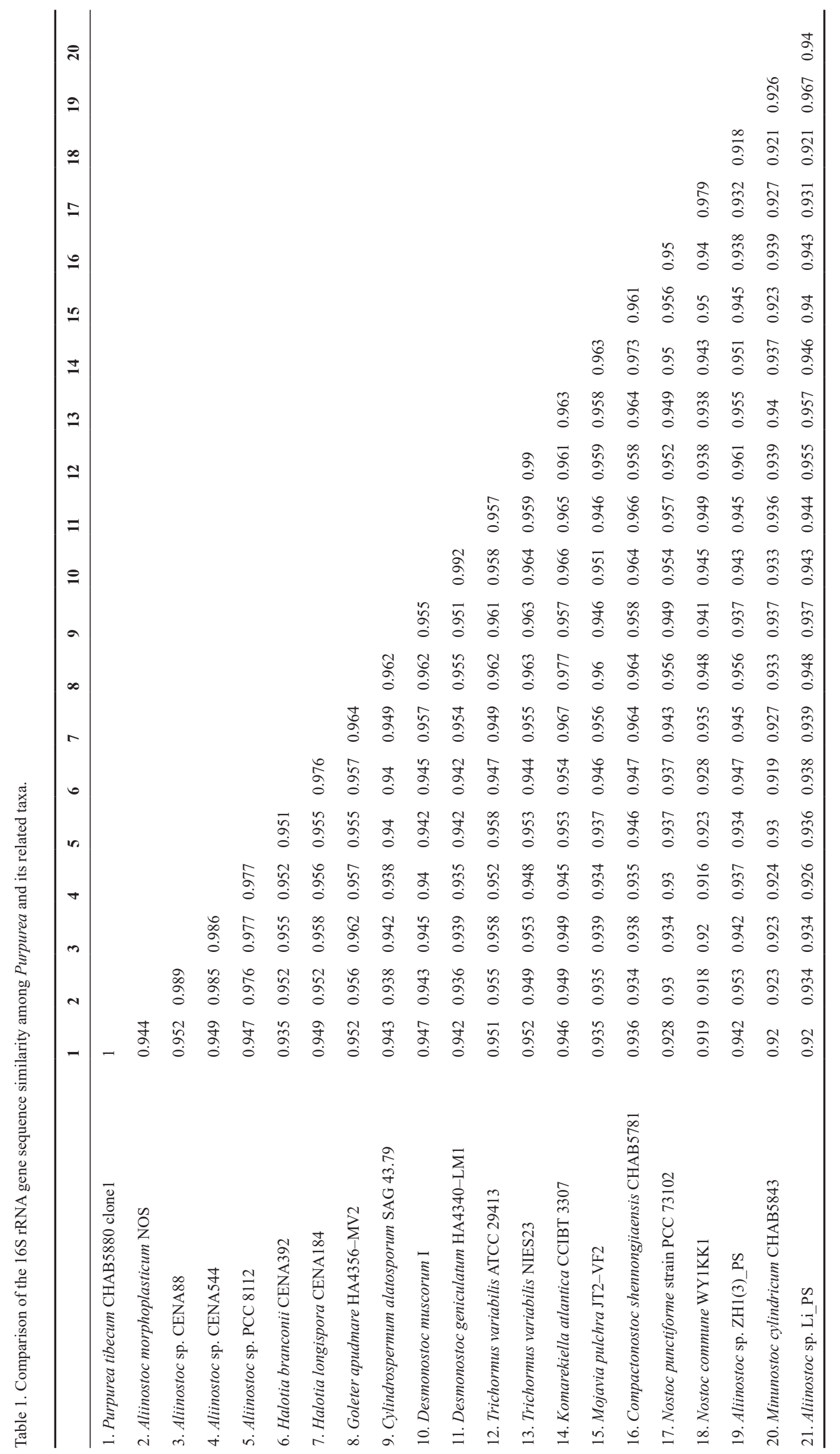


$94.2 \%-94.7 \%, 93.5 \%-94.9 \%$, and $91.9 \%-92.8 \%$, respectively. The phylogenetic trees, based on $16 \mathrm{~S}$ rRNA gene from 123 cyanobacterial taxa including strain CHAB5880, were constructed using the MP, ML and Bayesian methods. A Bayesian tree, shown in Fig. 2 , revealed that two clones of the strain CHAB5880 were grouped into a unique clade further supported by MP, ML and BI approaches with high bootstrap values as $100 \%, 100 \%$, and 1.00 , respectively. The phylogenetic tree supported phylogenetic monophyly for the Nostoc sensu stricto clade, as well as Desmonostoc, Compactonostoc, Minunostoc, Komarekiella, Mojavia, Aliinostoc, Halotia, etc.

\section{ITS secondary structures}

The ITS regions containing both tRNAs, from strain CHAB5880 in this study, together with the sequences derived from GenBank, were used to construct the ITS secondary structure. In total, three Nostoc species, two Desmonostoc species, one species for each genus of Aliinostoc, Halotia, Mojavia, Minunostoc, Goleter, Trichormus, Compactonostoc, Minunostoc and Purpurea strain CHAB5880 were used to infer their relationship within Nostocaceae.

Analyses on D1-D1' helix (Fig. 3) revealed similar arrangements in several genera. The basal stem of the strain CHAB5880 consisted of a 6-bp helix, followed by a $2: 7$ bp base bilateral bulge $(2: 6,2: 7$ and $3: 8$ base bilateral bulge respectively in Mojavia, Halotia and Komarekiella), the bilateral bulge was connected by a side loop with a single base on the $3^{\prime}$ side (other taxa do not have this structure), following this side loop was two bilateral bulges of 4:3, 4:5 bases; the terminal loop contained 4 bp bases ( 3 bases in Halotia, 5 bases in Nostoc and Mojavia, 6 bases in Trichormus).

Shown in Fig. 4, the Box-B helix of Purpurea tibecum CHAB5880 presented a unique structure when compared with other taxa. CHAB5880 consisted of 4 bp (AGCA) helix in the base of the stem, followed by a 1:2 base bilateral bulge, and then further followed by $2: 4$ and $2: 2$ base bilateral bulges, and the terminal loop contained 4 bp bases (GAAG) (Fig. 4N).

Furthermore, the V3 helix was also shown to be a variable helix, with the range of length from $35 \mathrm{bp}$ to 103 bp (Fig. 5). The V3 region of Purpurea tibecum CHAB5880 was quite distinct from those in all other taxa, with the basal stem containing a 7-bp helix followed by six bilateral bulges, and the terminal loop consisted of six nucleoside bases (GUAAAA). The base of the stem of Aliinostoc morphoplasticum NOS consisted of an 8-bp helix, followed by a bilateral bulge of $2: 3$ bases, and the terminal loop consisted of six nucleoside bases (GAAAAG). The basal stem of V3 in Nostoc species contained a 3-bp helix followed by one or two bilateral bulges (six in strains Nostoc lichenoides CNP-AK1). The V3 helices of recently established genera were also quite different from those of other taxa. The basal stem of V3 in Halotia branconii CENA392 contained a 9-bp helix, followed by a side loop with 3 unpaired bases on the 5' side (Fig. 5G). Whereas the stem of Trichormus anomalus HA4352-LM2 consisted of a 2-bp helix, followed by four bilateral bulges (Fig. 5J), and the V3 helix of Minunostoc consisted of very long stems (10 bp), followed by a 1:2 base bilateral bulge, and further followed by a 5 bp terminal loop (Fig. 5M). The base stem of Compactonostoc consisted of a 5-bp helix (GCCAG), followed by a side loop with a single base on the 3 ' side, and then by one 4:3 bases bilateral bulge and the terminal loop consisting of a 4 nucleoside bases (GGUU) (Fig. 5L). These results showed that 16S-23S ITS region with both tRNA encoding genes varied not only in the secondary structures of D1-D1', Box B and V3 helix, but also in the length of regions of the ITS. The alignment of the ITS regions constructed among the taxa closely related to Purpurea genus showed that Purpurea genus differed from other genera in the length of the ITS region (Table 2).

\section{Discussion}

Molecular phylogenetic results have led the classification of cyanobacteria to be extensively revised and reconstructed in recent years, and all species within a genus in the revised taxonomic system of cyanobacteria would form a monophyletic cluster (ANAGNOSTIDIS \& KomáreK 1985; KomÁreK et al. 2014; Miscoe et al. 2016). However, many cyanobacterial groups are polyphyletic at different levels (KoMÁREK et al. 2014; GENUÁRIO et al. 2015; HentsCHKE et al. 2017; BAGCHI et al. 2017; Buch et al. 2017). The main mission of cyanobacterial taxonomic revision is to separate evolutionarily unrelated taxa within a genus, and to ensure that genus should be a monophyletic group. In this study, the strain CHAB5880 was characterized on the basis of the polyphasic approach. Morphological examination of this strain initially identified it to be the member of the morphological complex Nostoc-like taxa. Since the Nostoc-like taxa are very difficult to differentiate only on the basis of morphological features, a thorough phylogenetic study was carried out to determine the correct taxonomic characterization of this strain.

In 16S rRNA gene based phylogenetic tree, it was shown that the strain CHAB5880 was placed in a unique clade at a completely distinct and different node. The phylogenetic analysis showed that nostocacean genera resulted in the formation of 15 clusters (Fig. 2), and taxa with the Nostoc morphotype formed clades A, B, C, D, E, F, G, H and I. Clade A consisted of sequences from the recently proposed genus Aliinostoc, which morphologically appear to be Nostoc-like, but the phylogenetic placement is in a separate group with high bootstrap values (85\%, 99\% and 0.91 in MP, ML and Bayesian analyses, respectively). Clade $\mathrm{B}$ also contained sequences from the recently described genus Halotia, with its type species 
Table 2. Nucleotide lengths of the regions of the 16S-23S ITS of several studied strains.

\begin{tabular}{|c|c|c|c|}
\hline Strains & D1-D1' & Box-B & V3 \\
\hline $\begin{array}{l}\text { Compactonostoc } \\
\text { shennongjiaensis CHAB5781 }\end{array}$ & 67 & 29 & 42 \\
\hline Nostoc commune WY1-KK1 & 69 & 39 & 101 \\
\hline Nostoc lichenoides $\mathrm{CNP}-\mathrm{AK} 1$ & 68 & 33 & 39 \\
\hline Nostoc punctiforme PCC73102 & 67 & 37 & 39 \\
\hline $\begin{array}{l}\text { Desmonostoc geniculatum } \\
\text { HA4340-LM1 }\end{array}$ & 65 & 50 & 90 \\
\hline $\begin{array}{l}\text { Desmonostoc danxiaense } \\
\text { CHAB5868 }\end{array}$ & 65 & 29 & 34 \\
\hline Mojavia pulchra JT2-VF2 & 64 & 28 & 103 \\
\hline Halotia branconii CENA392 & 65 & 39 & 44 \\
\hline $\begin{array}{l}\text { Komarekiella atlantica CCIBT } \\
3481\end{array}$ & 65 & 28 & 36 \\
\hline $\begin{array}{l}\text { Goleter apudmare HA4340- } \\
\text { LM2 }\end{array}$ & 65 & 30 & 35 \\
\hline $\begin{array}{l}\text { Minunostoc cylindricum } \\
\text { CHAB5843 }\end{array}$ & 107 & 50 & 36 \\
\hline $\begin{array}{l}\text { Trichormus anomalus } \\
\text { HA4352-LM2 }\end{array}$ & 66 & 28 & 82 \\
\hline $\begin{array}{l}\text { Aliinostoc morphoplasticum } \\
\text { NOS }\end{array}$ & 93 & 25 & 35 \\
\hline Purpurea tibecum CHAB5880 & 70 & 56 & 98 \\
\hline
\end{tabular}

Halotia branconii isolated from biofilms in Antarctica. Clade D is regarded as 'Nostoc sensu stricto', including seven species, and this core Nostoc clade was supported by high bootstrap values. Clades E, F, G, H and I contained sequences from the newly established genera Mojavia, Compactonostoc, Komarekiella, Desmonostoc and Minunostoc, respectively. Purpurea strain CHAB5880 was placed in clade $\mathrm{C}$, clearly outside the existing Nostoc-like clades, suggesting that this strain do not belong to any Nostoc-like genera. The Purpurea clade showed $<95 \%$ similarities to most of Nostoc-like genera such as Nostoc, Desmonostoc, Halotia, Komarekiella, Mojavia, Compactonostoc and Minunostoc, and similarities to Aliinostoc and Trichormus were 94.4\%-95.2\% and $95.1 \%-95.2 \%$. In bacteriology, the $95 \%$ similarity has been recommended as a cut-off for identification at the genus level (WAYNE et al. 1987; STACKEBRANDT \& Goebel 1994; StaCKebRANDT \& Ebers 2006). However, many researchers suggested that the $95 \%$ classification basis proposed by STACKEBRANDT \& GoEBEL (1994) cannot be used as an absolute criterion for separation of genera for most cyanobacteria (FLECHTNER et al. 2002; Casamatta et al. 2006; Johansen et al. 2014; ŘehÁKoví et al. 2014a; HENTSCHKE et al. 2017). The similarity of $16 \mathrm{~S}$ rRNA between the new proposed genus Komarekiella and other related genera in Nostocaceae (Anabaena, Cylindrospermum, Desmonostoc, Dolichospermum, Goleter, Halotia, Mojavia and Nostoc) were greater than $96 \%$. Some studies recognized that new genera can be proposed and established even with higher levels of 16S rRNA gene similarities to the existing genera, as long as phylogenetic or morphological evidences prove this recognition. The phylogenetic analysis revealed that Purpurea tibecum CHAB5880 stood alone and supported its separation from the existing Nostoc-like genera clades to become a new genus. However, in our study, we found that Aliinostoc soli ZH1(3)_PS and Aliinostoc tiwarii LI_PS were phylogenetically placed outside of the Aliinostoc cluster composed of the type species Aliinostoc morphoplasticum and other Aliinostoc strains. Furthermore, the $16 \mathrm{~S}$ rRNA gene sequence similarities between Aliinostoc soli ZH1(3)_PS, Aliinostoc tiwarii LI PS and other Aliinostoc strains were shown as nearly less than $95 \%$, below the bacterial genus cut-off. Thus, we suggest that the taxonomic status of Aliinostoc soli and Aliinostoc tiwarii should be separated from the Aliinostoc genus.

The establishment of Purpurea is also supported by the $16 \mathrm{~S}-23 \mathrm{~S}$ ITS secondary structure. The secondary structure of ITS between 16S-23S rRNA gene has been considered to be a powerful tool for delimitation of cyanobacterial species, among which D1-D1', Box-B and V3 helix are specifically important for separation of strains in different species (ITEMAN et al. 2000; VACCARINO \& JohanSEN 2012; Osorio-Santos et al. 2014; PietraSiaK et al. 2014; MAREŠ 2018). The secondary folding patterns of the 16S-23S ITS were very different from those of closely related taxa within Nostocaceae. D1-D1', Box-B and V3 helix of Purpurea were quite unique in comparison with those of Aliinostoc, Desmonostoc, Nostoc, Halotia, Minunostoc, Mojavia and Compactonostoc, enabling us to support the establishment of this new genus.

Considering the morphological features, CHAB5880 resembles the morphotypes of the related genera, Nostoc sensu stricto, Aliinostoc, Desmonostoc and Halotia. That being said, the identification of diacritical morphological features among these genera and species is apparently highly complex (Genuário et al. 2015). However, Purpurea differs from Nostoc, because the filaments do not form the spherical colonies which are characteristic of Nostoc, and Purpurea can be distinguished from Halotia since it does not form the aggregated filaments of microcolonies. When compared to Desmonostoc and Aliinostoc, it is shown that both Purpurea and Desmonostoc possess long, flexuous filaments and chains of akinetes, and Purpurea and Aliinostoc even possess the same type of cell division in trichomes. However, it is important that the purple black colour within vegetative cells and the formation of terminal heterocytes can be assumed to be important morphological traits distinguishing it from members of the genus Aliinostoc and Desmonostoc.

Many studies have emphasized the importance of ecological surveys in the classification of cyanobacteria 
(KomÁReK et al. 2014; KomÁreK 2016; BaGCHI et al. 2017; CAI et al. 2017; SABER et al. 2017), and it is worthy of mention that CHAB5880 is the first strain of the genus Purpurea isolated from wet soils in Tibet, China. The new cyanobacterial taxa described in this study emphasize the importance of exploration of underexplored environments to reveal the biodiversity of cyanobacteria.

When considered together, morphological, ecological, molecular and phylogenetic evidences obtained here make it reasonable to propose the novel cyanobacterial genus Purpurea, which represents a new monophyletic group in the cyanobacterial systematics.

\section{ACKNOWLEDGEMENTS}

The present study was funded by National Research Projects of 2014FY210700 and NSFC 31470310.

\section{REFERENCES}

ANAGNOSTIDIS, K. \& KoMÁREK, J. (1985): Modern approach to the classification system of cyanophytes. 1-Introduction. - Algological Studies/Archiv für Hydrobiologie Supplement Volumes: 291-302.
Bagchi, S.N.; Dubey, N. \& Singh, P. (2017): Phylogenetically distant clade of Nostoc-like taxa with the description of Aliinostoc gen. nov. and Aliinostoc morphoplasticum sp. nov. - International journal of systematic and evolutionary microbiology 67(9): 3329-3338.

BerRendero-Gómez, E.; Johansen, J.R.; KaštovskÝ, J.; BoHUNICKÁ, M. \& ČAPKOVÁ, K. (2016): Macrochaete gen. nov.(Nostocales, Cyanobacteria), a taxon morphologically and molecularly distinct from Calothrix.Journal of Phycology 52: 638-655.

BohunickÁ, M.; Pietrasiak, N.; Johansen, J.R.; Gómez, E.B.; Hauer, T.; Gaysina, L.A. \& LuKeŠová, A. (2015): Roholtiella, gen. nov.(Nostocales, Cyanobacteria)-a tapering and branching cyanobacteria of the family Nostocaceae. - Phytotaxa 197: 84-103.

Buch, B.; Martins, M.D. \& Branco, L.H.Z. (2017): A widespread cyanobacterium supported by polyphasic approach: proposition of Koinonema pervagatum gen. \& sp. nov. (Oscillatoriales). - Journal of Phycology 53:1097-1105.

CaI, F.; Chen, Y.; ZhU, M.; Li, X. \& LI, R. (2017): Desertifilum salkalinema sp. nov. (Oscillatoriales, Cyanobacteria) from an alkaline pool in China. - Phytotaxa 292: 262-270.

CAI, F.; Li, X.; YANG, Y.; JiA, N.; HuO, D. \& LI, R. (2019a): Compactonostoc shennongjiaensis gen. \& sp. nov. (Nostocales, Cyanobacteria) from a wet rocky wall
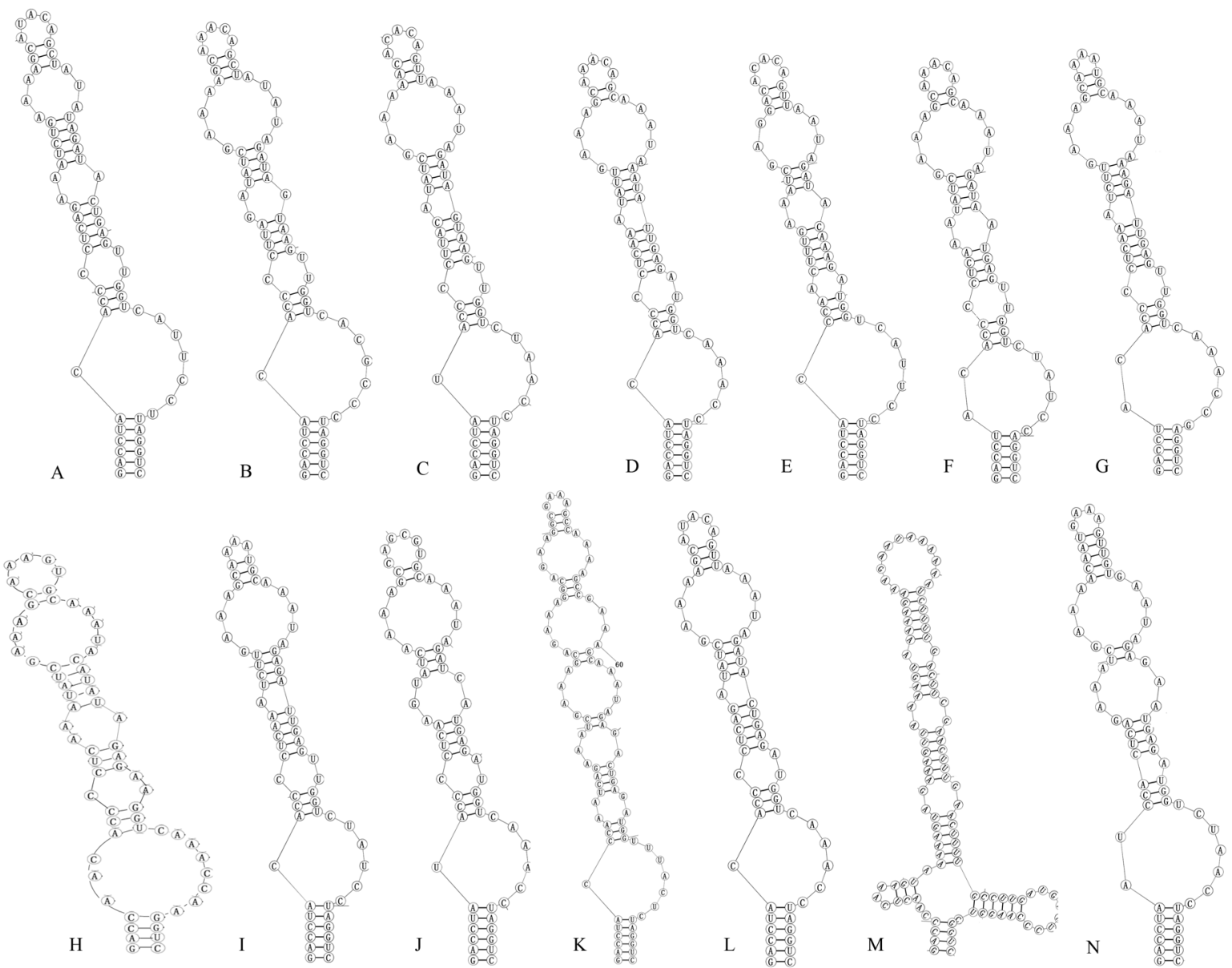

Fig. 3. D1-D1' helix in Purpurea tibecum and other heterocytous cyanobacteria: (A) Nostoc commune WY1-KK1; (B) Nostoc lichenoides CNP-AK1; (C) Nostoc punctiforme PCC73102; (D) Desmonostoc geniculatum HA4340-LM1; (E) Desmonostoc danxiaense CHAB5868; (F) Mojavia pulchra JT2-VF2; (G) Halotia branconii CENA392; (H) Komarekiella atlantica CCIBT 3481; (I) Goleter apudmare HA4340-LM2; (J) Trichormus anomalus HA4352-LM2; (K) Aliinostoc morphoplasticum NOS; (L) Compactonostoc shennongjiaensis CHAB5781; (M) Minunostoc cylindricum CHAB5843; (N) Purpurea tibecum CHAB5880. 
in China. - Phycologia 58: 200-210.

Cai, F.; Li, X.; Geng, R.; Peng, X. \& Li, R. (2019b): Phylogenetically distant clade of Nostoc-like taxa with the description of Minunostoc gen. nov. and Minunostoc cylindricum sp. nov. - Fottea 19: 13-24.

Casamatta, D.A.; Gomez, S.R. \& Johansen, J.R. (2006): Rexia erecta gen. et sp. nov. and Capsosira lowei sp. nov., two newly described cyanobacterial taxa from the Great Smoky Mountains National Park (USA). Hydrobiologia 561: 13-26.

Edwards, U.; Rogall, T.; Blocker, H.; Emde M. \& BotTger, E.C. (1989): Isolation and direct complete nucleotide determination of entire genes. Characterization of a gene coding for $16 \mathrm{~S}$ ribosomal RNA. - Nucleic Acids Research 17: 7843-7853.
FIore, M.F.; SANT'ANNA, C.L.; AzEVEDO, M.T.D.P.; KoMÁREK, J.; KAŠTOVsKÝ, J.; SULEK, J. \& LORENZI, A.A.S. (2007): The cyanobacterial genus Brasilonema, gen. nov., a molecular and phenotypic evaluation 1. - Journal of Phycology 43: 789-798.

Fiore, M.B.; Alvarenga, D.O.; GenuÁrio, D.B.; ANDreote, A.P.D.; HAUER, T. \& KoMÁReK, J. (2013): Dactylothamnos gen. nov., a novel member of Microchaetaceae isolated from extreme environments. - In: Book of abstracts, 19th Symposium of the International Society for Cyanophyte Research. - p. 22, Cleveland, Ohio.

Flechtner, V.R.; Boyer, S.L.; Johansen, J.R. \& Denoble, M.L. (2002): Spirirestis rafaelensis gen. et sp. nov. (Cyanophyceae), a new cyanobacterial genus from arid soils. - Nova Hedwigia 74: 1-24.
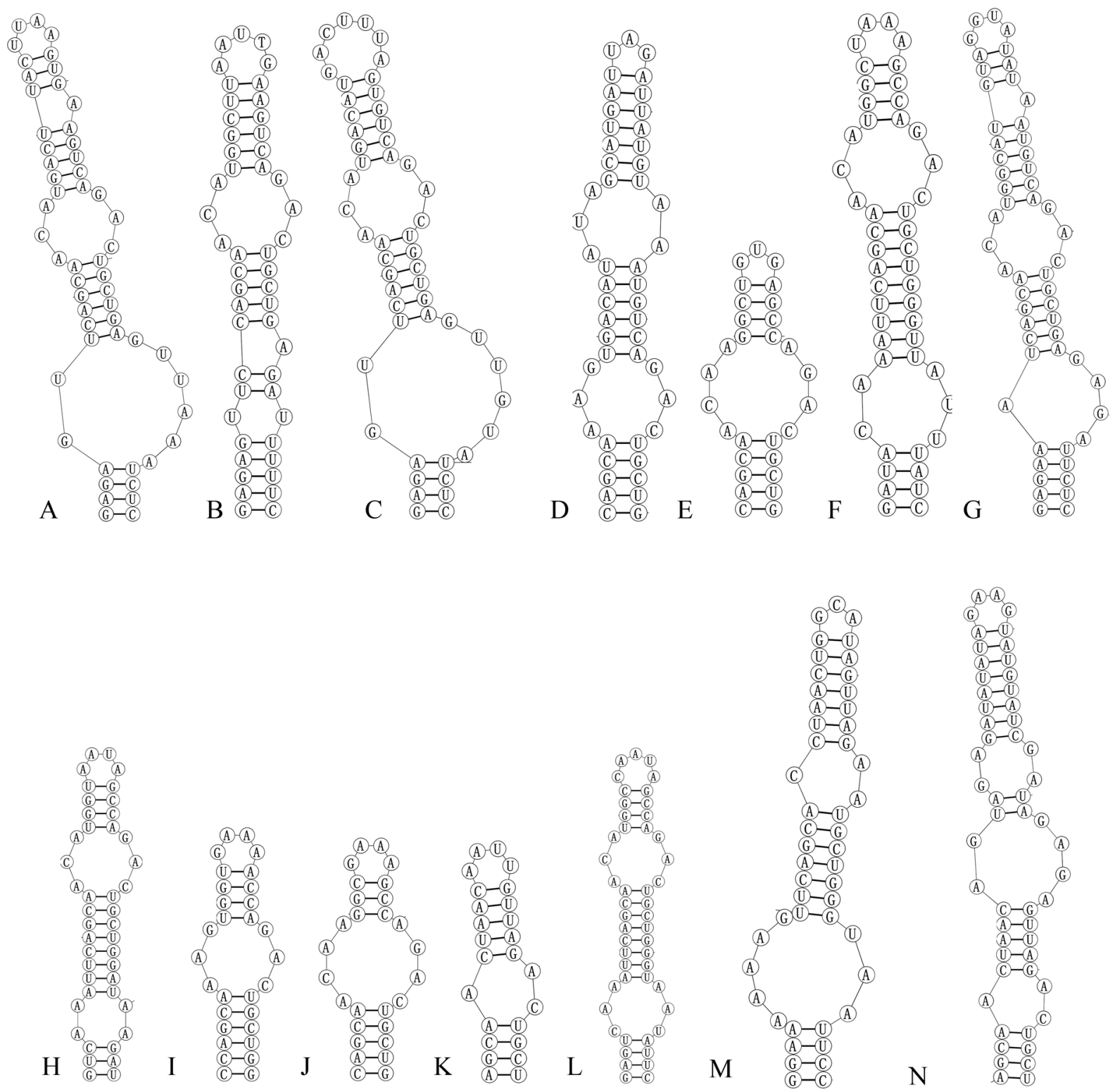

Fig. 4. Box-B helix in Purpurea tibecum and other heterocytous cyanobacteria: (A) Nostoc commune WY1-KK1; (B) Nostoc lichenoides CNP-AK1; (C) Nostoc punctiforme PCC73102; (D) Desmonostoc geniculatum HA4340-LM1; (E) Desmonostoc danxiaense CHAB5868; (F) Mojavia pulchra JT2-VF2; (G) Halotia branconii CENA392; (H) Komarekiella atlantica CCIBT 3481; (I) Goleter apudmare HA4340-LM2; (J) Trichormus anomalus HA4352-LM2; (K) Aliinostoc morphoplasticum NOS; (L) Compactonostoc shennongjiaensis CHAB5781; (M) Minunostoc cylindricum CHAB5843; (N) Purpurea tibecum CHAB5880. 
GenuÁRIO, D.B.; VAZ, M.G.M.V.; HentschKe, G.S.; SANT'AnNA, C.L. \& Fiore, M. F. (2015): Halotia gen. nov., a phylogenetically and physiologically coherent cyanobacterial genus isolated from marine coastal environments. International journal of systematic and evolutionary microbiology 65: 663-675.

Gkelis, S.; Rajaniemi, P.; VardaKa, E.; MoustaKa-Gouni,
M.; LANARAS, T. \& Sivonen, K. (2005): Limnothrix redekei (Van Goor) Meffert (Cyanobacteria) strains from Lake Kastoria, Greece form a separate phylogenetic group. - Microbial Ecology 49: 176-182.

GuIRY, M.D. \& GuIRY, G.M. (2019): AlgaeBase. World-wideelectronic publication, National University of Ireland, Galway. http://www.algaebase.org; searched on 15
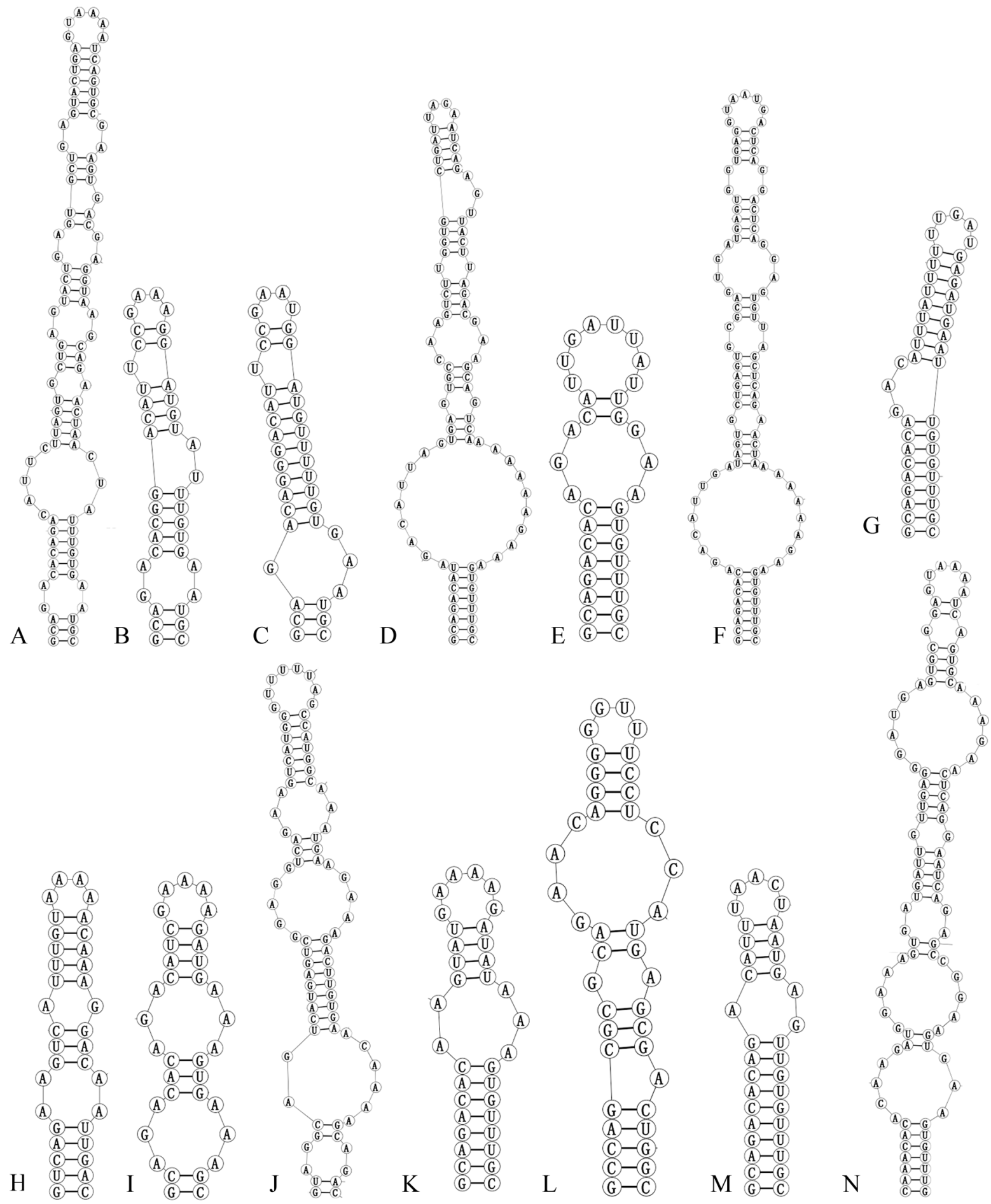

$\mathrm{F}+\frac{\mathrm{C}-\mathrm{C}}{\mathrm{C}-\mathrm{C}}$

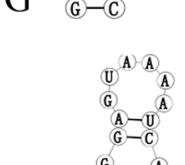

Fig. 5. V3 helix in Purpurea tibecum and other heterocytous cyanobacteria: (A) Nostoc lichenoides CNP-AK1; (B) Nostoc commune WY1-KK1; (C) Nostoc punctiforme PCC73102; (D) Desmonostoc geniculatum HA4340-LM1; (E) Desmonostoc danxiaense CHAB5868; (F) Mojavia pulchra JT2-VF2; (G) Halotia branconii CENA392; (H) Komarekiella atlantica CCIBT 3481; (I) Goleter apudmare HA4340-LM2; (J) Trichormus anomalus HA4352-LM2; (K) Aliinostoc morphoplasticum NOS; (L) Compactonostoc shennongjiaensis CHAB5781; (M) Minunostoc cylindricum CHAB5843; (N) Purpurea tibecum CHAB5880. 
July 2019.

Guindon, S.; Dufayard, J.F.; Lefort, V.; Anisimova, M.; HordiJK, W. \& GASCUEL, O. (2010): New algorithms and methods to estimate maximum-likelihood phylogenies: assessing the performance of PhyML 3.0. - Systematic biology 59: 307-321.

Hauer, T.; Mares, J.; Bohunicka, M.; Johansen, J.R. \& BerReNDERo-GoMez, E. (2014): Heterogeneity of the cyanobacterial genus Microchaete: reassessment of the family Microchaetaceae and establishment of new families Tolypothrichaceae and Godleyaceae. Journal of Phycology 50:1089-100.

Hentschke, G.S.; Johansen, J.R.; Pietrasiak, N., et al. (2016): Phylogenetic placement of Dapisostemon gen. nov. and Streptostemon, two tropical heterocytous genera (Cyanobacteria). - Phytotaxa 245: 129-143.

Hentschke, G.S.; Johansen, J.R.; Pietrasiak, N.; Rigonato, J.; Fiore, M.F. \& SANT'ANNA, C.L. (2017): Komarekiella atlantica gen. et sp. nov.(Nostocaceae, Cyanobacteria): a new subaerial taxon from the Atlantic Rainforest and Kauai, Hawaii. - Fottea 17: 178-190.

Hoffmann, L.; KomÁreK, J. \& KašTovskÝ, J. (2005a): System of cyanoprokaryotes (cyanobacteria) - state in 2004. Algological Studies 117: 95-115.

Hoffmann, L.; KomáReK, J.; KašTovskÝ, J. (2005b): Proposal of cyanobacterial system -2004. - In: Büdel, B.; Krienitz, L.; Gärtner, G. \& Schagerl, M. (eds): Süsswasserflora von Mitteleuropa 19/2. - p. 657-660, Elsevier/Spektrum, Heidelberg.

Hrouzek, P.; Ventura, S.; Lukešová, A.; Mugnai, M.A.; Turicchia, S. \& KomáreK, J. (2005): Diversity of soil Nostoc strains: phylogenetic and phenotypic variability. - Algological Studies 117: 251-264.

Iteman, I.; Rippka, R.; Tandeau, Demarsac, N.; Herdman, M. (2000): Comparison of conserved structural and regulatory domains within divergent $16 \mathrm{~S}$ rRNA-23S rRNA spacer sequences of cyanobacteria. - Microbiology 146: $1275-1286$

Johansen, J.R. \& Casamatta, D.A. (2005): Recognizing cyanobacterial diversity through adoption of a new species paradigm. - Algological Studies 116: 71-93.

JohANSEN, J.R.; BOHUNICKÁ, M.; LuKEŠOvÁ, A.; HrČKOVÁ, K.; VACCARINo, M.A. \& Chesarino, N.M. (2014): Morphological and molecular characterization within 26 strains of the genus Cylindrospermum (Nostocaceae, Cyanobacteria), with descriptions of three new species. - Journal of Phycology 50: 187-202.

Katoh, K. \& Standley, D.M. (2013): MAFFT multiple sequence alignment software version 7 : improvements in performance and usability. - Molecular Biology and Evolution 30: 772-780.

KAŠTOVSKÝ, J. \& JOHANSEN, J.R. (2008): Mastigocladus laminosus (Stigonematales, Cyanobacteria): Phylogenetic relationship of strains from thermal springs to soil inhabiting genera of the order and taxonomic implications for the genus. -Phycologia 47: 307-320

KaŠTovskÝ, J.; BerRendero-GoMeZ, E.; HLADIL, J. \& JoHANSEN, J.R. (2014): Cyanocohniella calida gen. nov. et spec. nov. (Cyanobacteria: Aphanizomenonaceae) a new cyanobacterium from the thermal springs from Karlovy Vary, Czech Republic. - Phytotaxa 181: 279-92.

KomáReK, J.; KaštovskÝ, J.; Mareš, J. \& Johansen, J.R. (2014): Taxonomic classification of cyanoprokaryotes (cyanobacterial genera) 2014, using a polyphasic approach. - Preslia 86: 295-335.
KomÁreK, J. (2016): A polyphasic approach for the taxonomy of cyanobacteria: principles and applications. - European Journal of Phycology 51: 346-353.

Kumar, S.; Stecher, G. \& TAmura, K. (2016): MEGA7: molecular evolutionary genetics analysis version 7.0 for bigger datasets. - Molecular biology and evolution 33: $1870-1874$.

Lukešová, A.; Johansen, J.R.; Martin, M.P.; Casamatta, D.A. (2009): Aulosira bohemensis sp. nov.: Further phylogenetic uncertainty at the base of the Nostocales (Cyanobacteria). - Phycologia 48:118-129.

MAREŠ, J. (2018): Multilocus and SSU rRNA gene phylogenetic analyses of available cyanobacterial genomes, and their relation to the current taxonomic system. Hydrobiologia 811: 19-34.

Mathews LAB. (2013): RNAstructure version 5.6. http://rna. urmc. rochester.edu/RNAstructure.html.

Miscoe, L.H.; Johansen, J.R.; VACCARINO, M.A.; PietrasiaK, N. \& SHERwood, A.R. (2016): The diatom flora and cyanobacteria from caves on Kauai, Hawaii. II. Novel cyanobacteria from caves on Kauai, Hawaii. - Bibliotheca Phycologica 123: 75-152.

NeIlan, B.A.; JaCOBS, D. \& Goodman, A.E. (1995): Genetic diversity and phylogeny of toxic cyanobacteria determined by DNA polymorphisms within the phycocyanin locus. - Applied and Environmental Microbiology 61: 3875-3883.

Osorio-Santos, K.; Pietrasiak, N.; Bohunická, M.; Miscoe, L.H.; KovéČIK, L.; MARTIN, M.P. \& JOHANSEN, J.R. (2014): Seven new species of Oculatella (Pseudanabaenales, Cyanobacteria): taxonomically recognizing cryptic diversification. - European journal of phycology 49: 450-470.

Posada, D. \& Crandall, K.A. (1998): Modeltest: testing the model of DNA substitution. - Bioinformatics 14: 817-818.

Pietrasiak, N.; Mühlsteinová, R.; Siegesmund, M.A. \& Johansen, J.R. (2014): Phylogenetic placement of Symplocastrum (Phormidiaceae, Cyanophyceae) with a new combination $S$. californicum and two new species: S. flechtnerae and S. torsivum. - Phycologia 53: 529-541.

Řeháková, K.; Johansen, J.R.; Casamatta, D.A; Xuesong, L. \& VINCENT, J. (2007): Morphological and molecular characterization of selected desert soil cyanobacteria: three species new to science including Mojavia pulchra gen. et sp. nov. - Phycologia 46: 481-502.

ŘehÁKovÁ, K.; Mareš, J.; LukeŠová, A.; ZaPomĚLová, E.; Bernardová, K. \& Hrouzek, P. (2014). Nodularia (Cyanobacteria, Nostocaceae): a phylogenetically uniform genus with variable phenotypes. - Phytotaxa 172: 235-246.

Rippka, R.; Deruelles, J.; Waterbury, J.B.; Herdman, M. \& StANIER, R.Y. (1979): Generic assignments, strain histories and properties of pure cultures of cyanobacteria. - Microbiology 111: 1-61.

Ronquist, F.; Teslenko, M.; Vandermark, P.; Ayres, D.L.; Darling, A.; Hohna, S.; Larget, B.; Liu, L.; Suchard, M.A. \& HuelsenbeCK, J.P. (2012): MrBayes 3.2: Efficient Bayesian Phylogenetic Inference and Model Choice Across a Large Model Space. - Systematic Biology 61: 539-42.

Saber, A.A.; Cantonati, M.; Mareš, J.; Anesi, A. \& Guella, G. (2017): Polyphasic characterization of Westiellopsis prolifica (Hapalosiphonaceae, Cyanobacteria) from 
the El-Farafra Oasis (Western Desert, Egypt). Phycologia 56: 697-709.

Sciuto, K., \& Moro, I. (2016): Detection of the new cosmopolitan genus Thermoleptolyngbya (Cyanobacteria, Leptolyngbyaceae) using the 16S rRNA gene and 16S-23S ITS region. - Molecular phylogenetics and evolution 105: 15-35.

Shalygin, S.; Shalygina, R.; Johansen, J.R.; Pietrasiak, N.; Berrendero-Gómez, E.; Bohunická, M.; Mareš, J. \& SHeIL, C.A. (2017): Cyanomargarita gen. nov. (Nostocales, Cyanobacteria): convergent evolution resulting in a cryptic genus. - Journal of Phycology 53: 762-777.

Stackebrandt, E. \& Goebel, B.M. (1994): Taxonomic note: a placefor DNA-DNA reassociation and $16 \mathrm{~S}$ rRNA sequence analysisin the present species definition in bacteriology. - International Journal of Systematic Bacteriology 44: 846-849.

STACKebrandT, E. \& Ebers, J. (2006): Taxonomic parameters revisited: tarnished gold standards. - Microbiol.Today 33: $152-155$

WAYNe, L.G.; BRENNER, D.J.; COLWELl, R.R.; GRIMONT, P.A.D.; KANDLER, O.; KRICHEVSKY, M.I. \& STARR, M.P. (1987): Report of the ad hoc committee on reconciliation of approaches to bacterial systematics. - International Journal of Systematic and Evolutionary Microbiology 37: 463-464.

WACKLIN, P.; HofFMANN, L. \& KoMÁREK, J. (2009): Nomenclatural validation of the genetically revised cyanobacterial genus Dolichospermum (Ralfs ex Bornet et Flahault) comb. nova. - Fottea 9: 59-64.

VACCARINO, M.A. \& Johansen, J.R. (2012): Brasilonema angustatum sp. nov. (Nostocales), a new filamentous cyanobacterial species from the Hawaiian Islands. Journal of Phycology 48: 1178-1186.

ZapomĚlová, E.; Jezberová, J.; HrouZeK, P.; Hisem, D.; Řeháková, K. \& Komárková, J. (2009): Polyphasic characterization of three strains of Anabaena reniformis and Aphanizomenon aphanizomenoides (Cyanobacteria) and their reclassification to Sphaerospermum gen. nov. (incl. Anabaena kisseleviana). - Journal of Phycology 46: 415.

Zapomělová, E.; Skácelová, O.; Pumann, P.; Kopp, R. \& JANEČEK, E. (2012): Biogeographically interesting planktonic Nostocales (Cyanobacteria) in the Czech Republic and their polyphasic evaluation resulting in taxonomic revisions of Anabaena bergii Ostenfeld 1908 (Chrysosporum gen. nov.) and A. tenericaulis Nygaard 1949 (Dolichospermum tenericaule comb. nova). - Hydrobiologia 698: 353-365.

(C) Czech Phycological Society (2020)

Received August 23, 2019

Accepted November 20, 2019 